\title{
Analysis of an L-Histidinol-utilizing Mutant of Pseudomonas aeruginosa
}

\author{
By M. R. DHAWALE* AND E. H. CREASER \\ Genetics Department, Research School of Biological Sciences, \\ The Australian National University, Canberra, A.C.T. 2601, Australia
}

(Received I8 October 1974; revised 6 June 1975)

\section{SUMMARY}

Transductional analysis was applied to the Pseudomonas aeruginosa mutant PAOI 4 ( $h n c-I)$. This mutant can utilize L-histidinol as sole source of carbon and nitrogen and has a 60-fold increased histidinol dehydrogenase (HDH) content (Dhawale, Creaser \& Loper, 1972). Transductional analysis was carried out using I 8 histidine-requiring mutants to see where the $h n c-I$ locus maps in relation to the structural genes of histidine biosynthesis. The hnc-I marker cotransduced with group IV genes at 97 to $100 \%$ and not at all with group I, which is known to be the structural gene for $\mathrm{HDH}$.

The data obtained in the studies of $K_{m}$ (histidinol) and $K_{m}$ (NAD), and the effect of $\mathrm{pH}$ and temperature on the HDH activity from PAOI and PAOI4 are in full agreement with the genetic data that the $h n c-r$ mutation is not in the structural gene for $\mathrm{HDH}$. It is suggested that $h n c-I$ may be a mutation in a regulatory gene affecting $\mathrm{HDH}$ synthesis in PAOI4 and may map close to his-IV whose function in histidine biosynthesis is not known.

\section{INTRODUCTION}

Previous work on the evolution of mechanisms for utilization of histidinol as sole source of carbon and nitrogen (Dhawale, Creaser \& Loper, 1972) showed that whereas Arthrobacter histidinolovorans produced a second, inducible enzyme system for the conversion of histidinol to histidine, Pseudomonas aeruginosa appeared to have developed a new control system for the increased formation of histidinol dehydrogenase (HDH).

We isolated a mutant of $P$. aeruginosa which can utilize histidinol (hnc- $I$ : PAOI4) as the sole source of nitrogen and carbon, and gives a 6o-fold increase in total HDH activity. However, polyacrylamide gel electrophoresis was unable to separate the enzyme activity of the mutant from that obtained from the parent strain PAOI grown on glucose plus minimal medium. The 'mutant' enzyme is inducible by histidinol and its synthesis is repressed by the catabolites of histidinol and histidine. It has been suggested that HDH produced by the mutant strain PAOI4 is the same as that synthesized by the wild-type strain (PAOI) grown on mineral salts, glucose and $\mathrm{NH}_{4} \mathrm{NO}_{3}$. To test this hypothesis further, two approaches were used. Firstly, a genetic analysis was carried out using histidine-requiring mutants in order to relate the hnc-I mutation to other genes of histidine biosynthesis in this bacterium. Secondly, the kinetic properties of the enzymes, which included $K_{m}$ (histidinol), $K_{m}$ (NAD), optimum $\mathrm{pH}$ and optimum temperature of the enzyme reaction were studied.

There appear to be at least five groups of genes involved in histidine biosynthesis in $P$.

* Present address: Laboratory of Biochemistry, National Cancer Institute, Bethesda, Maryland, $200 \mathrm{I} 4$, U.S.A. 
aeruginosa (Mee \& Lee, 1967) which are reported to be unlinked (Fargie \& Holloway, I965). Mee \& Lee (1969) proposed a map order for group I genes, and phenotypes of the alleles have been examined in relation to the map order.

\section{METHODS}

Media. All percentages are w/v. Nutrient broth (NYB): Difco nutrient broth, $0.8 \%$; Difco yeast extract, $0.5 \%$. Nutrient agar (NA): Oxoid blood agar base, $4 \%$; Oxoid yeast extract, $0.5 \%$. Layer agar (LA) for phage assay: NYB plus $0.8 \%$ Ionagar No. 2 (Oxoid). Minimal medium (MM) was that of Vogel \& Bonner (1956) solidified with I \% Ionagar No. 2 (Oxoid). Supplemented minimal media (SMM): appropriate sterile solutions (sterilized by filtering through a $0.45 \mu \mathrm{m}$ Millipore filter) of D- or L-amino acids were added to $\mathrm{MM}$ to give a final concentration of $100 \mu \mathrm{g} / \mathrm{ml}$, except isoleucine and valine (ilv), which were added to give final concentrations of 50 and $100 \mu \mathrm{g} / \mathrm{ml}$, respectively, and solidified with $\mathrm{I} \%$ Ionagar No. 2 (Oxoid). Pseudomonas mineral medium (PMM): $\mathrm{K}_{2} \mathrm{HPO}_{4}, 0 \cdot 15 \% ; \mathrm{KH}_{2} \mathrm{PO}_{4}$, $0.05 \% ; \mathrm{MgSo}_{4} \cdot \mathrm{H}_{2} \mathrm{O}, 0.02 \%$ (Tabor \& Hayaishi, 1952). Histidinol medium (HM): PMM supplemented with L-histidinol (solution sterilized separately by filtering through a $0.45 \mu \mathrm{m}$ Millipore filter) at a concentration of 0.5 to $\mathrm{I} \cdot 0 \mathrm{mg} / \mathrm{ml}$, and solidified with $\mathrm{I} \%$ Ionagar No. 2 (Oxoid) for plates.

Bacterial strains. Pseudomonas aeruginosa strain PaOI4 ( $h n c-I)$ was derived from strain PAOI after treatment with $N$-methyl- $N^{\prime}$-nitro- $N$-nitrosoguanidine (NTG) (Dhawale et al. I972). Other strains are listed in Table $\mathrm{I}$.

Bacteriophage strain. Transducing phage Gro (Holloway, Krishnapillai \& Stanisich, I97I) contains double-stranded DNA with a molecular weight of $38 \times 10^{6}$ daltons. Gior gives more cotransduction than transducing phage Fi 6 (V. Krishnapillai, personal communication). Phage GIOI was propagated on strain PAOI4 by the agar layer method, sterilized by filtration through a $0.45 \mu \mathrm{m}$ Millipore filter, checked for bacterial count, stored sterile at $4{ }^{\circ} \mathrm{C}$ and used within a month.

Transduction experiment. Preparations of the transducing phage Gior were adjusted to a titre of $10^{9}$ plaque-forming units (p.f.u.)/ml with TMM buffer (tris, $0.12 \mathrm{I} \%$; sodium chloride, $0.877 \% ; \mathrm{MgSO}_{4} .7 \mathrm{H}_{2} \mathrm{O}, 0.246 \%$; adjusted to $\mathrm{pH} 7.4$ with $\mathrm{I} \mathrm{M}-\mathrm{HCl}$, autoclaved at I $5 \mathrm{lb} / \mathrm{in}^{2}$ for $20 \mathrm{~min}$ ). The recipient strains (Table I) were grown overnight in Io $\mathrm{ml} \mathrm{NYB}$ at $37^{\circ} \mathrm{C}$. Exponential-phase cultures were obtained by inoculating $\mathrm{I} \mathrm{ml}$ of overnight-grown cultures into $30 \mathrm{ml}$ of prewarmed NYB and aerating at $37^{\circ} \mathrm{C}$ for 2.5 to $3 \mathrm{~h}$. Samples (IO ml) were centrifuged in a bench centrifuge for $15 \mathrm{~min}$ and the cell pellet resuspended in $2 \mathrm{ml}$ sterilized saline (0.14 $\mathrm{M}-\mathrm{NaCl})$. An equal volume of donor phage preparation was added to the suspension and the mixture incubated at $37^{\circ} \mathrm{C}$ for $20 \mathrm{~min}$. After absorption, the mixture was centrifuged and the pellet resuspended to the same volume in saline. Samples $(0.2 \mathrm{ml})$ were then plated on to MM or SMM by spreading with a glass spreader. The plates were incubated at $37^{\circ} \mathrm{C}$ for $48 \mathrm{~h}$ before counting the transductants.

Characterization of transductants. Transductants were partially purified by spotting the colonies on to a plate of the same medium on which the transduction was performed. After overnight growth at $37^{\circ} \mathrm{C}$, this was used as the master plate in replicating on to different supplemented medium, NA, MM or HM plates. Cotransduction of the $h n c-I$ marker was determined by replicating on to HM (supplemented with the required amino acid) plates. Replica plates were incubated at $37^{\circ} \mathrm{C}$ for $48 \mathrm{~h}$ before the segregation of non-selected marker or selected marker was determined. Maleness of the strain was determined (PAOI302 and GMAI 30) using NA plates supplemented with $40 \mu \mathrm{g} \mathrm{HgCl}_{2} / \mathrm{ml}$ (Holloway et al. 197I). Trans- 
Table I. Pseudomonas aeruginosa strains used

\begin{tabular}{|c|c|c|}
\hline Strain* & Markers $\uparrow$ & Description \\
\hline PAOI & & Wild type \\
\hline PAO7 & his-I, met-28 & Methionine-, histidine-requiring mutant \\
\hline PAOI 4 & $h n c-I$ & $\begin{array}{l}\text { L-Histidinol-utilizing mutant isolated by treat- } \\
\text { ment of NTG on PAOI }\end{array}$ \\
\hline PAO27 & ser-3, his-33 & Serine-, histidine-requiring mutant \\
\hline PA067 & his-67, ese-2 & $\begin{array}{l}\text { Histidine-requiring, phage E 79-resistant } \\
\text { mutant }\end{array}$ \\
\hline PAO73 & his-7o, ese-2 & $\begin{array}{l}\text { Histidine-requiring, phage } \mathrm{E} \text { 79-resistant } \\
\text { mutant }\end{array}$ \\
\hline PAO246 & his-3, met-28, trp-6, lys-56 & $\begin{array}{l}\text { Histidine-, methionine-, tryptophan- and } \\
\text { lysine-requiring mutant }\end{array}$ \\
\hline PAOI 302 & $h i s-16 I, \mathrm{FP}^{+}$ & Histidine-requiring mutant, male strain \\
\hline PAOI 65I & his-I 71, met-28, ilv 282 & $\begin{array}{l}\text { Histidine-, methionine- and isoleucine-valine- } \\
\text { requiring mutant }\end{array}$ \\
\hline M2355 & his-5037 & Histidine-requiring mutant \\
\hline M2356 & his-5039 & Histidine-requiring mutant \\
\hline M2357 & his-5044 & Histidine-requiring mutant \\
\hline M2360 & his-5065 & Histidine-requiring mutant \\
\hline GMAO34 & his-5034, ade-5034 & Histidine- and adenine-requiring mutant \\
\hline GMAO35 & his- 5035 & Histidine-requiring mutant \\
\hline GMAI 22 & his-69 & Histidine-requiring mutant \\
\hline GMAI 30 & $h i s-64$, trp-4, FP+ & $\begin{array}{l}\text { Histidine- and tryptophan-requiring mutant, } \\
\text { male strain }\end{array}$ \\
\hline GMAI 47 & his-23, ade-66 & Histidine- and adenine-requiring mutant \\
\hline GMAI 56 & his- 49, ade- 66 & Histidine- and adenine-requiring mutant \\
\hline GMAI 59 & his -9, cys -5242 & Histidine- and cysteine-requiring mutant \\
\hline
\end{tabular}

* Strains prefixed PAo were obtained from Professor B. W. Holloway, strains prefixed M from Dr B. J. Mee, and strains prefixed GMA from Dr A. H. C. Kung.

$\dagger$ This nomenclature follows Demerec et al. (1966).

ductants were tested for immunity to the lysogenizing phage GIOI by either streaking against phage on NA or by replicating on to a NA plate spread with $0.1 \mathrm{ml}$ phage suspension.

Preparation of crude extracts of Pseudomonas aeruginosa strains PAOI and PAOI4. Pseudomonas aeruginosa strain PAOI was grown in I 1 PMM supplemented with I \% glucose and $0.2 \% \mathrm{NH}_{4} \mathrm{NO}_{3}$. The medium was shaken at $37^{\circ} \mathrm{C}$ after inoculating with a colony of culture grown overnight on a NA plate. The strain PAOI 4 was grown in I 1 PMM supplemented with $0.05 \%$ histidinol. The medium was shaken at $37^{\circ} \mathrm{C}$ after inoculating with a colony grown overnight on a HM plate. The cultures were harvested when they reached stationary phase. Cells were collected by centrifugation at $13000 \mathrm{~g}$ for $20 \mathrm{~min}$. Cells were suspended in $\mathrm{I} 0 \mathrm{ml}$ tris- $\mathrm{HCl}$ buffer ( $\mathrm{pH} 9 . \mathrm{I}, 0.05 \mathrm{M}$ ) containing $0.1 \%$ 2-mercaptoethanol, and sonicated with ice-cooling for $5 \mathrm{~min}$ each in an MSE $100 \mathrm{~W}$ disintegrator. The resultant extracts were used directly for enzyme assays.

Partial purification of histidinol dehydrogenase. The method for partial purification of HDH from various strains of $P$. aeruginosa was as described by Dhawale et al. (1972).

Estimation of protein. Protein was estimated by the method of Lowry et al. (I95I) using bovine albumin fraction $\mathrm{V}$ (Sigma) as standard.

Enzyme assays. L-Histidinol dehydrogenase was assayed by NAD reduction, measuring the rate of increase in $E_{340}$ at $37^{\circ} \mathrm{C}$ (Creaser, Bennett \& Drysdale, 1967). A spectrophotometer cuvette (Io mm light path) contained $0.7 \mathrm{ml}$ of glycine- $\mathrm{NaOH}$ buffer, $\mathrm{pH} 9.8(3.78 \mathrm{~g}$ glycine adjusted to $\mathrm{pH} 9.8$ with I $\mathrm{M}-\mathrm{Na} \mathrm{OH}$ and made up to I l) containing $0.1 \%$ (v/v) 2-mercaptoethanol, $O^{\circ} \mathrm{I} \mathrm{ml}$ aqueous NAD ( $\mathrm{I} \mu \mathrm{mol}$ ) and $0 . \mathrm{I} \mathrm{ml}$ of the enzyme solution under test. 
The mixture was incubated at $37^{\circ} \mathrm{C}$ in the cell for 2 min and then $0.1 \mathrm{ml}(0.2 \mu \mathrm{mol})$ of L-histidinol dihydrochloride solution was added to initiate the reaction. NAD reduction was then measured. Enzyme activities are expressed in nmoles NAD reduced per minute (mu).

Phosphoribosyl-ATP (PR-ATP) synthetase activity can be measured as described by Voll, Apella \& Martin (1967), which is based upon the measurement of the relatively high extinction coefficient of PR-ATP at $290 \mathrm{~nm}$. A Io mm spectrophotometer cuvette contained $0.15 \mathrm{ml}$ buffer salt solution ( $0.2 \mathrm{M}$-tris- $\mathrm{HCl} \mathrm{pH} 8.5,0.02 \mathrm{M}-\mathrm{MgCl}_{2}, 0.3 \mathrm{M}-\mathrm{KCl}$ ), Io $\mu$ l pyrophosphatase (O.I mg/ml, Sigma), $20 \mu \mathrm{l}$ ATP (O.I M), enzyme solution, and water to make $0.95 \mathrm{ml}$. The reaction was started by adding $50 \mu \mathrm{l}$ phosphoribosyl pyrophosphate (PRPP) (6.6 mM in $20 \mathrm{~mm}$-EDTA at $\mathrm{pH}$ 7). The preparation was mixed and the increase in extinction at $290 \mathrm{~nm}$ and $37^{\circ} \mathrm{C}$ was recorded. One unit of activity corresponds to the formation of $0.00167 \mu \mathrm{mol}$ PR-ATP $/ \mathrm{min}-\mathrm{a} \Delta E_{290}$ of $0.05 / \mathrm{min}$.

Imidazole glycerol phosphate (IGP) dehydratase activity was determined by the method of Ames (1957). Imidazole acetol phosphate (IAP) formed from IGP absorbs strongly in the ultraviolet and was measured at $290 \mathrm{~nm}$ after enolization. A reaction mixture contains $0.6 \mathrm{ml}$ of the assay mixture $(5 \mathrm{ml}$ of $0 . \mathrm{I} \mathrm{M}$-triethanolamine $\mathrm{pH} 8 . \mathrm{I}, 30 \mu \mathrm{l}$ of $\mathrm{I} 4.3 \mathrm{M}-3$-mercaptoethanol, Io $\mu \mathrm{l}$ of $0.1 \mathrm{M}-\mathrm{MnCl}_{2}$ ) and 20 to $100 \mu \mathrm{l}$ enzyme. The reaction is started with $20 \mu \mathrm{l}$ of IGP (O.I M, synthesized according to the procedure of Ames, 1957). A blank with water in place of IGP was carried through the procedure. The mixture was incubated at $37^{\circ} \mathrm{C}$ for $30 \mathrm{~min}$ and was stopped by the addition of $\mathrm{I} \cdot 38 \mathrm{ml}$ of $\mathrm{I} \cdot 43 \mathrm{M}-\mathrm{NaOH}$. The mixture was re-incubated at $37^{\circ} \mathrm{C}$ for $30 \mathrm{~min}$ to accomplish the enolization of IAP formed. A blank measured the $E_{290}$ without enzyme. One unit of enzyme forms I $\mu \mathrm{mol} \mathrm{IAP} / \mathrm{h}$, resulting in a $\Delta E_{290}$ of $5 \cdot \mathrm{I}$.

Histidinol phosphate (HP) phosphatase assay was based on the determination of inorganic phosphate released in the reaction, according to Ames, Hartman \& Jacob (I963). The enzyme $(0.1 \mathrm{ml})$ was added to the buffer (triethanolamine- $\mathrm{HCl} ; 0 . \mathrm{I} \mathrm{M}, \mathrm{pH} 7.5)$ to a final volume of $0.29 \mathrm{ml}$. A blank without enzyme was brought to $0.3 \mathrm{ml}$. The reaction was initiated with $10 \mu \mathrm{l}$ of histidinol phosphate ( $50 \mathrm{~mm}$; Calbiochem), and the assay mixture incubated at $37{ }^{\circ} \mathrm{C}$ for $15 \mathrm{~min}$. At the end of $15 \mathrm{~min}, 0.7 \mathrm{ml}$ of colour-developing mixture was added (I part of $10 \%$ ascorbic acid plus 6 parts of $0.42 \%$ ammonium molybdate in $0.5 \mathrm{M}$ phosphate-free $\mathrm{H}_{2} \mathrm{SO}_{4}$ ). The colour was developed by incubating the mixture at $45^{\circ} \mathrm{C}$ for $20 \mathrm{~min}$. The precipitate was discarded following centrifugation for $10 \mathrm{~min}$ in a bench centrifuge. The colour of the resulting supernatant was measured at $820 \mathrm{~nm}$ against the blank. Values were corrected by assaying a control (minus enzyme, plus histidinol phosphate). One unit of activity lead to the formation of $\mathrm{I}$ unit of extinction in $15 \mathrm{~min}$ at $820 \mathrm{~nm}$, or one unit of enzyme hydrolysed $0.0385 \mu \mathrm{mol}$ histidinol phosphate $/ \mathrm{I} 5 \mathrm{~min}$ at $37^{\circ} \mathrm{C}$.

IAP-glutamate aminotransferase activity was measured by the method of Martin \& Goldberger (1967), which measures the extinction of imidazole acetol phosphate when it is enolized in strong alkali. The reaction was run in the reverse direction so that formation of IAP from histidinol phosphate could be measured at $280 \mathrm{~nm}$. The reaction mixture contained $0.4 \mathrm{ml}$ buffer (triethanolamine- $\mathrm{HCl} ; 0.2 \mathrm{M}, \mathrm{pH} 8.6$ ), $10 \mu 1$ 2-ketoglutarate $(0.2 \mathrm{M}$, pH 6.0) and enzyme (20 to I00 $\mu \mathrm{l}$ ). The reaction was started by the addition of Io $\mu \mathrm{l}$ of histidinol phosphate ( $50 \mathrm{~mm}$ ) and the mixture incubated at $37^{\circ} \mathrm{C}$ for $\mathrm{I} 5 \mathrm{~min}$. A blank with water was carried through the assay procedure. The reaction and blank were stopped by the addition of $\mathrm{I} \cdot 4 \mathrm{ml}$ of $\mathrm{I} \cdot 43 \mathrm{M}-\mathrm{NaOH}$ and re-incubated at $45^{\circ} \mathrm{C}$ for $20 \mathrm{~min}$ to enolize the IAP formed. The resulting $E_{280}$ was measured against a blank. One unit of enzyme activity yielded an extinction of $\mathrm{I}$, or converted $0.188 \mu \mathrm{mol}$ histidinol phosphate to IAP at $37{ }^{\circ} \mathrm{C}$ every $15 \mathrm{~min}$. 
Table 2. Transductional analysis of I8 histidine-requiring mutants of P. aeruginosa

Transductants were selected only for $\mathrm{His}^{+}$. Transducing donor phage GIOI was propagated on strain PAOI4 (hnc-I).

\begin{tabular}{|c|c|c|c|c|}
\hline Recipient strain & Group no. & $\begin{array}{c}\text { No. of } \\
\text { transductants/ } \\
10^{9} \text { donor phage }\end{array}$ & $\begin{array}{l}\text { No. of } \\
\text { transductants } \\
\text { scored }\end{array}$ & $\begin{array}{l}\text { No. of } \\
\text { transductants } \\
\text { carrying } \\
\text { hnc-I marker }\end{array}$ \\
\hline PAO7 & I & 88 & 100 & 0 \\
\hline PAO27 & IV & 130 & 100 & 100 \\
\hline PA067 & II & 148 & 100 & 0 \\
\hline PAO73 & IV & 2 & 44 & 43 \\
\hline PAO246 & IV & 25 & I64 & 164 \\
\hline PAOI 302 & $?$ & 28 & 100 & 0 \\
\hline PAOI 65I & $?$ & 0 & 0 & 0 \\
\hline M2356 & I & 2 & 32 & 0 \\
\hline M2357 & II & 24 & 86 & 0 \\
\hline $\mathrm{M} 2360$ & III & 5 & I 2 I & 0 \\
\hline M2355 & V & 0 & 0 & 0 \\
\hline GMAI 30 & IV & 95 & 100 & 100 \\
\hline GMAI 47 & I & 15 & 62 & 0 \\
\hline GMAI 56 & I & 12 & 84 & 0 \\
\hline GMAO34 & I & 17 & 65 & 0 \\
\hline GMAO35 & V & 5 & 40 & 0 \\
\hline GMAI 22 & II & $2 I$ & 84 & 0 \\
\hline GMA I 59 & I & 13 & 65 & 0 \\
\hline
\end{tabular}

\section{RESULTS AND DISCUSSION}

Of I 8 histidine-requiring mutants of $P$. aeruginosa tested, all were negative for $h n c-I$ marker (i.e. they do not show utilization of histidinol as sole source of nitrogen and carbon). However, for the growth of these His- mutants in $\mathrm{PMM}+$ glucose $+\mathrm{NH}_{4} \mathrm{NO}_{3}$ medium, histidine (growth requirement) could be replaced by histidinol, which indicates that inability to use histidinol as sole source of nitrogen and carbon cannot be due to impermeability.

Transductional analysis of these $18 \mathrm{His}^{-}$mutants which fall into five groups, using PAOI4 ( $h n c-I$ ) as donor and selecting for His ${ }^{+}$transductants and then scoring for $h n c-I$ marker, showed that this marker is cotransducible with his alleles of group IV at about 97 to $100 \%$ (Table 2). Although all these mutants adsorb the transducing phage GroI at similar levels and form plaques at the same efficiency, they gave different frequencies of $\mathrm{His}^{+}$transductants.

When the experiment was repeated using the group IV strain PAO246 as recipient but first selecting for $h n c-I, 28$ transductants were obtained: all 28 were $h i s-3^{-}$. From the previous experiment we can infer that all 28 should be his- $3^{+}$, cotransduction being $100 \%$ with this recipient. The simplest explanation is that the his- $3^{+}$gene was cotransduced but that growth on histidinol had in some way resulted in its not being expressed. Further transductional work on the 28 isolates was not feasible as they were all Gror lysogens.

\section{Kinetic properties of $\mathrm{HDH}$ in P. aeruginosa}

Double reciprocal plots of the concentration of the substrate (histidinol) or co-factor (NAD), and the velocity of the reaction catalysed by $\mathrm{HDH}$ were employed to calculate the Michelis constants. They showed that $K_{m}$ (histidinol) and $K_{m}$ (NAD) for HDH produced by the mutant strain PAOI4 are the same as that for HDH produced by the wild-type strain PAOI (Fig. $1 a, b$ ). The plots of HDH activity versus temperature (Fig. 2a) and pH (Fig. $2 b$ ) 

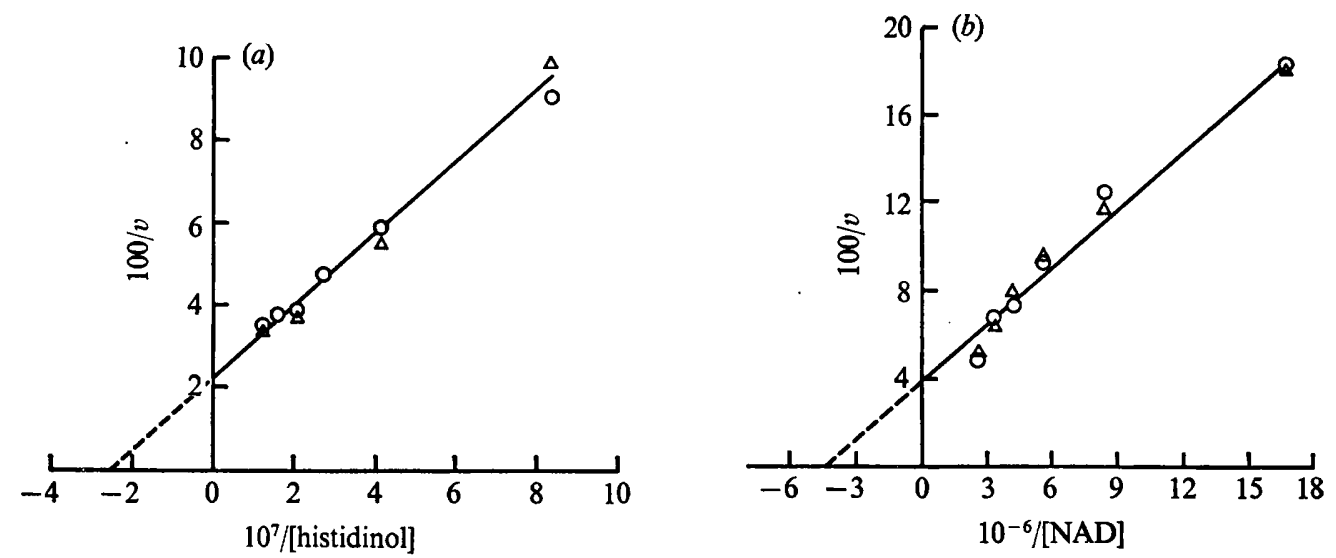

Fig. I. Lineweaver-Burk plot to determine (a) $K_{m}$ (histidinol) and (b) $K_{m}$ (NAD) of histidinol dehydrogenase in $P$. aeruginosa strains PAOI and PAOI4. $\triangle$, Strain PAOI; $O$, strain PAOI4. Activity was measured in a $\mathrm{I} \mathrm{ml} \mathrm{total} \mathrm{volume} \mathrm{of} \mathrm{glycine-} \mathrm{NaOH}$ buffer, $\mathrm{pH} 9.8$, containing $0.1 \% 2-$ mercaptoethanol. For the determination of $K_{m}$, either $(a)$ I $\mu$ mol NAD, or $(b) 0.2 \mu$ mol histidinol, each in $0.1 \mathrm{ml}$, plus $0.1 \mathrm{ml}$ enzyme solution were added and the mixture incubated in the spectrophotometer cuvette for $2 \mathrm{~min}$ before initiation of the reaction by the addition of $(a) 8$ to 80 nmol histidinol solution, or $(b) 4$ to 40 nmol NAD solution. The initial velocity $v$ is expressed in milliunits.
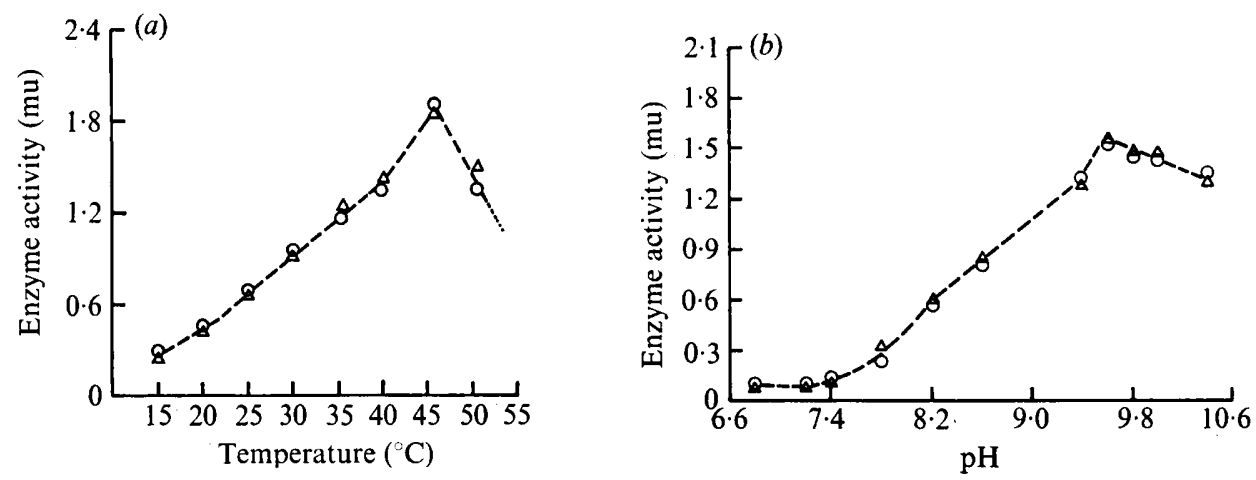

Fig. 2. Effect of $(a)$ temperature and $(b) \mathrm{pH}$ on the activity of histidinol dehydrogenase in $P$. aeruginosa strains PAOI and PAOI4. $\triangle$, Strain PAOI; $\bigcirc$, strain PAOI4. Activities were measured in $\mathrm{ml}$ total

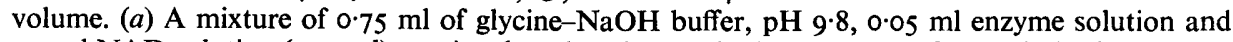
$0.1 \mathrm{ml}$ NAD solution ( $\mu \mathrm{mol}$ ) was incubated at the required temperature for $5 \mathrm{~min}$ in the spectrophotometer cuvette. The reaction was initiated by the addition of $0.1 \mathrm{ml}$ of $\mathrm{L}$-histidinol solution $(0.2 \mu \mathrm{mol})$. NAD reduction was then measured. Temperature was regulated by means of a water circulator. (b) All buffers were $0.05 \mathrm{M}$, and contained $0.1 \%$ 2-mercaptoethanol. Buffers of $\mathrm{pH}$ values 8.6 to 10.4 were glycine- $\mathrm{NaOH}$, and 7.2 to 8.2 were tris- $\mathrm{HCl}$; buffer of $\mathrm{pH} 6.8$ was sodiumpotassium phosphate.

indicate that the HDH produced by both the strains (PAOI and PAOI4) express maximal activity at a $\mathrm{pH}$ value of 9.6 and at a temperature of $46^{\circ} \mathrm{C}$ (Table 3 ).

\section{Effect of hnc-I mutation on activities of other enzymes of histidine biosynthesis}

Having observed a marked increase in $\mathrm{HDH}$ activity in P. aeruginosa strain PAOI4, it is of interest to know the effect of $h n c-I$ mutation on the other enzymes of histidine biosynthesis. Enzyme assays were carried out using crude extracts of strain PAOI grown on PMM + glucose $+\mathrm{NH}_{4} \mathrm{NO}_{3}$ and of PAOI4 grown on histidinol medium. The results (Table 4 ) indicate a 
Table 3. Kinetic properties of partially purified $H D H$ produced by $P$. aeruginosa strains PAOI and PAOI 4

\author{
$K_{m}$ (histidinol) \\ $K_{m}$ (NAD) \\ Optimum pH \\ Optimum temperature
}
$3 \cdot 9 \times 10^{-5} \mathrm{M}$
$2 \cdot 3 \times 10^{-4} \mathrm{M}$
$9 \cdot 6$
$46^{\circ} \mathrm{C}$

Table 4. Specific activities of enzymes of histidine biosynthesis in strains of $P$. aeruginosa

$\begin{array}{lll}\text { Enzymes tested } & \text { ND } & \text { ND } \\ \text { Phosphoribosyl-ATP synthetase } & 0.61 & 0.52 \\ \text { IGP dehydratase } & 0.1 \mathrm{I} & 0.15 \\ \text { HP phosphatase } & 0.18 & 0.10 \\ \text { IAP glutamate aminotransferase } & 0.054 & 8.6 \\ \text { Histidinol dehydrogenase* } & \text { PAOI4 } \\ \text { ND, Not detectable. } \quad * \text { Activity expressed as mu/mg protein. }\end{array}$

Table 5. HDH specific activity in histidine requiring mutants of $P$. aeruginosa

HDH specific
activity
(mu/mg protein)

ND, Not detectable.

slight decrease in IGP dehydratase activity and increase in HP phosphatase activity in strain PAOI4 which were not significant when compared with the activities in strain PAOI. Activity of the enzyme IAP glutamate aminotransferase in strain PAOI was about twice that of strain PAOI 4. In both the strains PR-ATP synthetase activity was undetectable. These data suggest that the $h n c-I$ mutation does not cause any significant alteration in the levels of enzymes tested, other than $\mathrm{HDH}$.

In $P$. aeruginosa, histidine groups II, IV and V are suggested as not being involved in the control of HDH synthesis. This is based on the fact that mutants from these groups show the presence of $\mathrm{HDH}$ activity with varying levels (see Table 5). As group III mutants can take up histidinol when supplied in place of histidine as a growth requirement with $\mathrm{MM}$, this suggests that the group III mutant is not devoid of HDH activity, but cells synthesize the enzyme to such a small extent that it was not detectable by the assay system. On comparison of the HDH enzyme produced by strain PAOI 4 grown on HM, and that produced by wild-type strain PAOI grown on $\mathrm{PMM}+$ glucose $+\mathrm{NH}_{4} \mathrm{NO}_{3}$, these show similar enzyme kinetics, similar optimum $\mathrm{pH}$ and temperature for expression of maximal activity, and are indistinguishable electrophoretically (Dhawale et al. 1972). If we assume that mutation or mutations in a structural gene(s) must affect the nature of the enzyme produced by the gene(s), then one must postulate that on the basis of information available, the hnc-I mu- 
tation is not in the structural gene but must be in a second gene. Further support for this postulation comes from the transductional analysis of his mutants of P. aeruginosa (Table 2). The $h n c-I$ mutation has shown a clear relationship to group IV genes. Group I is considered to be a structural gene for HDH synthesis in P. aeruginosa (Mee \& Lee, I969), and therefore the structural gene and hypothesized second gene map at quite separate regions of the chromosome.

The higher induced level of HDH enzyme in this mutant (PAOI4) can be explained in that the mutant may be accumulating a higher cell concentration of effector molecules (histidinol), which may be due to the effect of altered membrane permeability. Existence of two highaffinity transport systems in $P$. aeruginosa which recognize tryptophan, phenylalanine and tyrosine, has been reported by Kay \& Gronlund (I97I). In strain PAOI an active transport system may be present only for histidine but not for histidinol. Mutants which cannot make histidine but are not blocked at the HDH step are presumed to be able to take up histidinol by a general low-efficiency permease or by passive diffusion. The hnc-I mutation may have produced an altered permease system specific for histidinol. We are investigating this possibility.

\section{REFERENCES}

AmEs, B. N. (I 957). The biosynthesis of histidine: D-erythro-imidazole-glycerol-phosphate dehydratase. Journal of Biological Chemistry 228, I 3 I-I 43.

Ames, B. N., HaRtman, P. E. \& JACOB, F. (I963). Chromosomal alterations affecting the regulation of histidine biosynthetic enzymes in Salmonella. Journal of Molecular Biology 7, 23-42.

Creaser, E. H., Bennett, D. J. \& Drysdale, R. B. (1967). The purification and properties of histidinol dehydrogenase from Neurospora crassa. Biochemical Journal no3, 36-4I.

Demerec, M., Adelberg, E. A., Clark, A. J. \& Hartman, P. E. (1966). A proposal for a uniform nomenclature in bacterial genetics. Genetics $54,6 \mathrm{I}-76$.

Dhawale, M. R., Creaser, E. H. \& Loper, J. C. (1972). Evolutionary mechanism of adaptation of Arthrobacter histidinolovorans and Pseudomonas aeruginosa to use L-histidinol as a sole source of nitrogen and carbon. Journal of General Microbiology 73, 353-358.

Fargie, B. \& Holloway, B. W. (I965). Absence of clustering of functionally related genes in Pseudomonas aeruginosa. Genetical Research 6, 284-299.

Holloway, B. W., Krishnapillai, V. \& Stanisich, V. (I97I). Pseudomonas genetics. Annual Review of Genetics 5, 425-446.

KAY, W. W. \& Gronlund, A. F. (I97I). Transport of aromatic amino acids by Pseudomonas aeruginosa. Journal of Bacteriology 105, I039-1046.

Lowry, O. H., Rosebrough, N. J., Farr, A. L. \& Randall, R. J. (I95I). Protein measurement with the Folin phenol reagent. Journal of Biological Chemistry 193, 265-275.

Martin, R. G. \& Goldberger, R. F. (I967). Imidazole acetolphosphate: L-glutamate aminotransferase. Purification and physical properties. Journal of Biological Chemistry 242, I $168-1$ I 74 .

MeE, B. J. \& LEE, B. T. O. (1967). Analysis of histidine requiring mutants of Pseudomonas aeruginosa. Genetics 55, 709-722.

MeE, B. J. \& LeE, B. T. O. (I969). A map order of his-I, one of the genetic regions controlling histidine biosynthesis in Pseudomonas aeruginosa, using transducing phage FII6. Genetics 62, 687-696.

TABOR, H. \& HAYAISHI, O. (I952). The enzymatic conversion of histidine to glutamic acid. Journal of Biological Chemistry 194, 17 I-I 75.

Vogel, H. J. \& BonNer, D. M. (1956). Acetylornithinase of Escherichia coli: partial purification and some properties. Journal of Biological Chemistry 218, 97-106.

Voll, M. J., Apella, E. \& Martin, R. G. (1967). Purification and composition studies of phosphoribosylATP: pyrophosphate phosphoribosyl transferase, the first enzyme of histidine biosynthesis. Journal of Biological Chemistry 242, $1760-1767$. 